Max-Planck-Institut für demografische Forschung

Max Planck Institute for Demographic Research

Konrad-Zuse-Strasse $1 \cdot$ D-18057 Rostock · GERMANY

Tel +49 (0) 3812081 - 0; Fax +49 (0) 3812081 - 202;

http://www.demogr.mpg.de

MPIDR WORKING PAPER WP 2007-025

AUGUST 2007

\title{
Premarital conception and divorce risk in Russia in light of the GGS data
}

Aiva Jasilioniene (jasilioniene@demogr.mpg.de)

This working paper has been approved for release by: Vladimir M. Shkolnikov (shkolnikov@demogr.mpg.de), Head of the Laboratory for Demographic Data.

(C) Copyright is held by the authors.

Working papers of the Max Planck Institute for Demographic Research receive only limited review. Views or opinions expressed in working papers are attributable to the authors and do not necessarily reflect those of the Institute. 


\begin{abstract}
The paper provides an analysis of divorce risk in first marital unions in Russia, with a major focus on the impact of premarital conception on the stability of subsequent marriage. A number of other predictors are also discussed, including age at first marriage, parity and age of the youngest child, parental divorce, place of residence, religion group and calendar period. The analysis is based on data from the Russian Generations and Gender Survey (GGS) carried out in 2004 and applies event history techniques. The results show that marriages induced by pregnancy run a higher divorce risk compared to those contracted without anticipation of childbirth.
\end{abstract}

Contents:

1. Introduction

2. Non-marital conceptions and divorce trends in Russia

3. Theoretical considerations

4. Data and methods

5. Results

6. Discussion of results and conclusions

7. Acknowledgements

References

Appendix 


\section{Introduction}

Russia has long been characterized by high divorce rates compared to western European countries, but due to a lack of necessary data, the determinants of this phenomenon have not yet been thoroughly analyzed. Prior research has often focused on analyzing the composition of the population by marital status and its changes as well as general divorce trends (Ilyina, 1994; Avdeev and Monnier, 2000; Vishnevsky, 2006). Several studies have investigated change in marital patterns, applying a life table technique. Using a multistate life table approach, Darsky and Scherbov (1995) described marital careers of women from fifteen republics of the former Soviet Union, including Russia, on the basis of the 1989 census data. Scherbov and van Vianen (1999) conducted an analysis of marital and fertility careers of Russian women born between 1910 and 1934 using data from the 1994 microcensus and later extended it to cohorts born between 1900 and 1960 (in Scherbov and van Vianen, 2001). A recent paper by Philipov and Jasilioniene (2007), comparing union formation and fertility trends in Bulgaria and Russia also reports on divorce in Russia, and provides life tables constructed for both synthetic and real cohorts.

Two recent studies by Muszynska shed more light on the determinants of union dissolution in Russia, but they consider all unions, making no distinction between marital and non-marital unions. The studies are based on linked data from the Russian Generations and Gender Survey (GGS) conducted in 2004 and the Russian Education and Employment Survey ${ }^{1}$ conducted in 2005. The first study (Muszynska, 2006a) examines how women's employment influences the risk of union dissolution; the other looks into the effect of family migration on union dissolution (Muszynska, 2006b).

The purpose of this paper is to study the determinants of divorce in first marriage in Russia. We use data from the 2004 Russian GGS, which provide detailed individuallevel information on union formation and childbearing and enable an explanatory analysis. Although many predictors of divorce are discussed, this paper takes as its central point of the analysis the effect of premarital conception on the stability of subsequent marriage. Generally, legitimating of premarital conception by marriage was a common practice in Russia in the past, when bearing a child out of wedlock was heavily condemned by the conservative society. Today in Russia, as in all other postcommunist countries, the second demographic transition is taking place, in which cohabitation as well as non-marital childbearing is becoming increasingly widespread. However, even today, as available evidence shows, many couples still marry as soon as they find out about the pregnancy. Thus, in this paper we intend to test whether marital unions, which are formed after and presumably because of conception, are at higher risk of breakup than other marital unions.

The paper is structured in the following way. Section 2 gives a short overview of trends in non-marital conceptions and divorce in Russia. Section 3 presents theoretical considerations and some results of previous research on divorce. Section 4 provides information about the data and method used and presents covariates included in the

\footnotetext{
${ }^{1}$ The Russian Education and Employment Survey represents a sub-sample of the Russian Generations and Gender Survey (GGS). It provides more detailed education, employment and migration histories.
} 
study. In section 5, we turn to the analysis of empirical findings. Section 6 concludes with a summary and a short discussion of our results.

\section{Divorce and non-marital conceptions in Russia: description of trends}

The high level of divorce in Russia is not just a recently observed development, but rather a long-standing trend. Already in the 1960s and 1970s, Russian divorce rates lay close to those of Western countries and were even among the highest in this respect (see Table 1).

Table 1: Total divorce rate

\begin{tabular}{lccccccc}
\hline & 1960 & 1970 & 1980 & 1990 & 1995 & 2000 & 2004 \\
\hline Russia & 0.17 & 0.34 & 0.42 & 0.40 & 0.50 & - & - \\
UK & - & 0.16 & 0.38 & 0.42 & 0.43 & - & - \\
Denmark & 0.19 & 0.25 & 0.40 & 0.44 & 0.41 & 0.45 & 0.47 \\
Sweden & 0.16 & 0.23 & 0.42 & 0.44 & 0.52 & 0.55 & 0.52 \\
Norway & 0.09 & 0.13 & 0.25 & 0.43 & 0.45 & 0.45 & 0.49 \\
Finland & 0.11 & 0.17 & 0.28 & 0.42 & 0.48 & 0.51 & 0.50 \\
Austria & 0.14 & 0.18 & 0.26 & 0.33 & 0.38 & 0.43 & 0.46 \\
Belgium & - & 0.10 & 0.21 & 0.31 & 0.55 & 0.45 & - \\
Netherlands & 0.07 & 0.11 & 0.25 & 0.30 & 0.36 & 0.38 & 0.35 \\
France & 0.10 & 0.12 & 0.22 & 0.32 & 0.38 & 0.38 & - \\
\hline Source:
\end{tabular}

The total divorce rate (TDR), which takes into account the age and marital status of the population, is a more specific measure than the crude divorce rate (CDR); however, due to incomplete divorce statistics, the total divorce rate is not available for Russia for the years 1997 onwards. On the other hand, as one can see from Figure 1, both measures display extremely similar dynamics in Russia. According to divorce statistics provided by Vishnevsky (1996), in 1950 the CDR in Russia was as low as 0.5 per 1000 of population. From then on, it rose steeply up to the level of 4.3 in 1979 . The steep rise is partly explained by the simplification of the divorce process in 1965 (Moskoff, 1983; Avdeev and Monnier, 2000). During the 1980s, the divorce rate remained high, but rather stable. However, the subsequent period witnessed exceedingly abrupt fluctuations with the lowest value of 3.4 in 1998 and the highest value of 5.9 in 2002. The analysis based on the 1994 microcensus of the Russian Federation shows that divorce in Russia has been growing with each successive younger cohort, starting with the oldest cohort, born in 1910 (Scherbov and van Vianen, 2004). 
Figure 1: Total divorce rate and crude divorce rate in Russia, 1960-2004

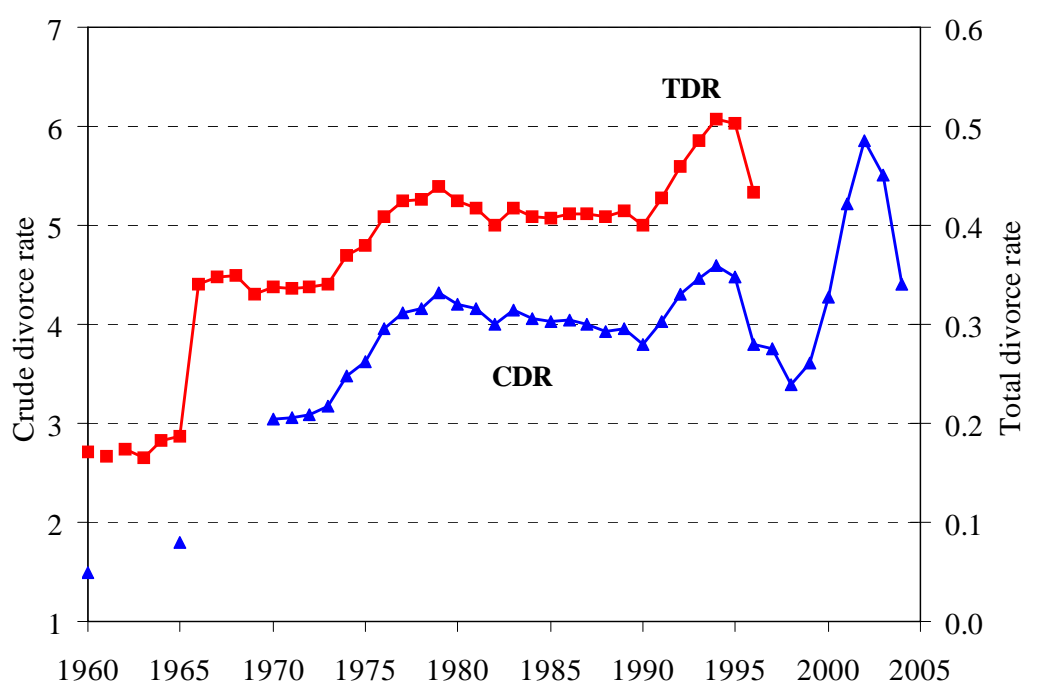

Source: Council of Europe, 2006; Generations \& Gender Contextual Database, 2006; Avdeev and Monnier, 2000.

For non-marital births, available evidence suggests that first sexual relations occurred relatively early in Russia as early as in the 1960s, often outside marriage (Avdeev and Monnier, 2000). The availability of efficient contraception was very low until the 1990s and therefore early sexual relations often produced unplanned premarital conceptions. Avoiding societal disapproval and stigmatization, many couples tried to legitimate their union as soon as they became aware of the pregnancy. The trend towards marriage at ever younger ages and the increasing incidence of premarital conceptions are assumed to be associated processes. As long as the social pressure prevented premarital childbearing, the proportion of children born out of wedlock decreased, but later on, along with the crucial ideational changes, it started to rise (Zakharov and Ivanova, 1996).

Figure 2: Non-marital births in Russia, 1960-2004

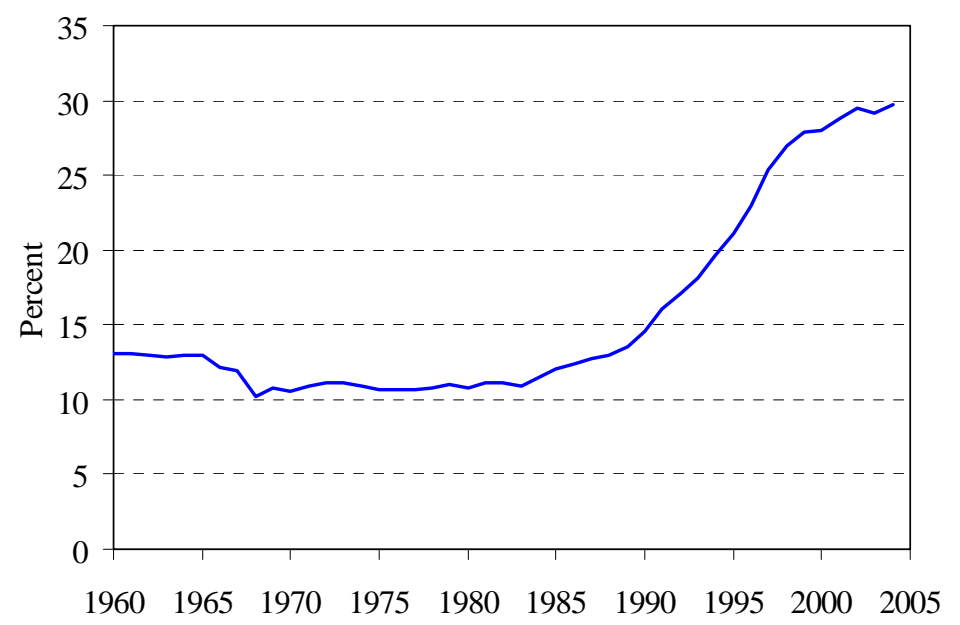

Source: Council of Europe, 2006. 
In the period from 1960 to 1968, the level of non-marital births fell from 13.1 percent to 10.3 percent. Until the early 1980s, there was a period of relative stabilization, after which the rapid increase followed. In 2004, the proportion of non-marital births reached 29.8 percent (see Figure 2). For most of the recent decades, the proportion of non-marital births was higher in rural areas of Russia than in urban areas. This was partly due to higher gender disproportions in the population groups of marrying age and partly due to lower contraceptive knowledge as well as more limited access to abortion in rural areas. However, in the 1990s the trends essentially converged (Zakharov and Ivanova, 2001).

The fact that the sharp rise in non-marital childbearing in the 1990s was accompanied by increasing access to and usage of contraception (Troitskaya and Andersson, 2007) leads to the assumption that most recent non-marital births are likely to be intentional. Increasingly more of these children have been registered by both parents (Tolts, Antonova, Andreev, 2006), which again points to the loosening of the bond between marriage and fertility and the increasing tendency to bear children in non-marital unions.

Notwithstanding the observed increase in non-marital births and the more liberal societal environment towards non-marital unions and childbearing within them, the proportion of premarital conceptions remains rather high in Russia. According to various studies conducted in different areas of Russia in the 1970s and 1980s, the proportion of premarital conceptions comprised about 30 to 40 percent of first births in marital unions (the conception is considered premarital if the difference between entry into marriage and birth of the child is no more than eight months) (Ivanova and Mikheeva, 1998). The corresponding estimate for 2002 using birth certificate data shows that more than 35 percent of all first children born inside wedlock were actually born less than nine months after the registration of marriage. These children constituted 25 percent of all marital births,. The share of premarital conceptions was higher among urban than rural women (26 and 22 percent respectively). The highest proportion of premarital conceptions was in the group of women aged 17-19. As to first births only, approximately $50 \%$ of first children born to married women aged 1819 were conceived before marriage (Tolts, Antonova and Andreev, 2005, 2006).

Thus, shotgun marriages are still relatively common in Russia, and our aim is to assess the stability of these marriages compared to marriages entered without the necessity to legitimate the birth.

\section{Theoretical considerations}

Marital dissolution is associated with an extremely wide range of factors of demographic, social, economic and psychological origin. It is not just an event, but a process affected by the way one's life evolves in terms of education, professional career, housing, etc. Appropriate changes in personal characteristics, attitudes, values and aspirations occur over time. However, previous research found that demographic factors are more significant predictors of divorce than socio-economic ones. Partnership history, age at marriage, timing of childbearing, including premarital birth and premarital conception, etc. seem to be more accountable for marital breakdown 
that educational level, social status or religion (Murphy, 1985; Clarke and Berrington, 1999).

In this section, we overview various theoretical considerations and findings of previous studies on the predictors of divorce. We have no pretensions that this overview is exhaustive and all-embracing; instead, we focus on the factors that are crucial and meaningful for this particular study.

\section{Motherhood status at marriage}

A substantial amount of research has attempted to find out what effect the timing of first birth has on the stability of marriage, i.e. how much it depends on whether the first child was born before marriage, soon after marriage or many years after marriage. It may also happen that the child never arrives. A common finding is that the sequence of marriage and first birth is rather important for the stability of marriage. Premarital conceptions and especially premarital births tend to increase the likelihood of divorce (Becker, Landes and Michael, 1977; Murphy, 1985; Morgan and Rindfuss, 1985; Hoem and Hoem, 1992; Kravdal, 1988; Teachman and Polonko, 1990; Andersson, 1997; Lyngstad, 2006; Waite and Lillard, 1991). The excess risk of marital dissolution among women who had a child before marriage is independent of who is the father of the child. Even if it is a common child with the husband, these women face a much higher risk of divorce than those who had their first birth in wedlock (Kravdal, 1988; Liu, 2002). Childless couples usually run the highest risk of marital breakdown, but we discuss this association more explicitly in the later section on the effect of number and ages of children.

Marital conceptions create the best protection against marital dissolution. However, there is no evidence suggesting that the delay of first birth until several years after marriage leads to higher stability of marriage as compared to earlier marital births (Morgan and Rindfuss, 1985).

The increased risk of divorce caused by premarital conception is commonly attributed to the haste in which forced ("shotgun") marriage is usually contracted. Premarital conceptions shorten the available time for searching out and dating the best potential partner.. The couples have less time to get to know each other and to build stable and firm relationships (Becker, Landes and Michael, 1977; Morgan and Rindfuss, 1985; Hoem and Hoem, 1992). Secondly, entry into marriage requires some inevitable adjustments in life, which may be much more difficult to do in cases where the wife is pregnant at marriage. The arrival of the first child is found to have a certain destabilizing effect on the marital relationship (Hoem, 1997), and if the couple has not had enough time to establish strong bonds, one may expect that the event will be even more detrimental to marriage. The same reasons account for the higher risk of divorce among women with premarital children. In addition, these women have already gone through being a single parent and therefore feel less terrified by the normative pressure. If the husband is not the biological father of the child(ren) born before marriage, it again reduces the preventive effect of parenthood (Morgan and Rindfuss, 1985). 


\section{Number and ages of children}

The literature discussing the effect of children on the stability of marriage suggests that having children contributes to the cohesiveness of the couple and reduces the risk of divorce. Children constitute "marital-specific capital" (Becker, Landes and Michael, 1977) and therefore raise the value of marriage as well as the costs of its dissolution (Becker, Landes and Michael, 1977; Waite and Lillard, 1991; Lillard and Waite, 1993). The presence of children creates legal, financial and emotional barriers against divorce, but at the same time more children do not necessary mean that the protection is higher.

Available evidence suggests that the lowest risk of divorce is among couples with two children and that the effect of subsequent births is less important. In a number of studies, it was found that the distribution of divorce risk by the number of children is U-shaped, being lowest among couples with two children and highest among the childless and those with four or more children (Murphy, 1985; Hoem and Hoem, 1992; Andersson, 1997; Liu, 2002).

Not only the presence and the number, but also the ages of children are important predictors of the divorce risk. Rates of divorce have been found to decrease after the arrival of the child and to be lowest when the child is young. As the child grows older, the risk of marital breakdown rises (Andersson, 1997; Kravdal, 1988; Becker, Landes and Michael, 1977; Lutz, Wils and Nieminen, 1991). Waite and Lillard (1991) found that the age of the child has the strongest effect for first-borns. First-born children enhance the stability of their parents' marriage through their preschool years, while subsequent children decrease the probability of divorce only when they are very young.

\section{Age at marriage}

Age at marriage is another important predictor of divorce. As reported in previous studies, people who marry at young ages usually have a higher risk of divorce than those who form first marital unions at later ages (Murphy, 1985; White, 1990; Morgan and Rindfuss, 1985; Andersson, 1997).

Similarly to the case of premarital conception discussed earlier in this paper, economic theorists reason that the higher probability of divorce arises from insufficient partner search as well as lack of maturity to select a compatible spouse (Becker Landes and Michael, 1977). Those who marry very young are not emotionally enough prepared for marriage and lack knowledge of how to maintain the relationship. Morgan and Rindfuss (1985) point to the importance of changes in individual characteristics that are taking place during one's late 'teens and early twenties. The younger the couple, the higher is the risk of withdrawing from each other over time due to increasing differences in interests, views and aspirations.

Some studies support the argument that the association between age at marriage and divorce reflects the effect of social class as people from poorer backgrounds tend to marry at younger ages (see Clarke and Berrington, 1999). 
In addition, some researchers argue that individuals who marry at younger ages may have particular personality traits that make them more inclined both to marry early and to end their marriages by divorce. They may be hastier in their decisions and more prone to rebellious behavior (Hoem and Hoem, 1992).

\section{Parental divorce}

A number of studies reveal the existence of intergenerational transmission of divorce. Children whose parents divorced appear to be more prone to dissolve their marriages than those whose parents form a stable couple (de Graaf and Kalmijn, 2006). The association persists even among those who were already adults when their parents divorced (see Clarke and Berrington, 1999).

It is believed that the disruptive effect of parents' divorce on children's future marriages operates through socialization. Children of divorced parents have higher risk of interpersonal behavior problems such as lack of trust in others or inability to commit. Experience of parental divorce diminishes psychological barriers to divorce and makes it easier to view as an acceptable solution in case of marital failure (Amato, 1996; Sanjian, 1991). These people are much more likely than others to cohabit before marriage (Thornton, 1991).

\section{Duration of marriage}

Previous research has found that the lowest probability of marital disruption is during the first year of marriage, and then it increases with every subsequent year. The risk of divorce reaches the peak between the duration of five to ten years and then falls again (Kravdal, 1988; Andersson, 1997; Lyngstad, 2004).

One of the explanations for these changes in divorce risk is that during the first decade of marriage both partners go through crucial life course transitions and challenging experiences (completion of education, building educational career, bearing children, etc.). During the later years, their life is more settled, the couple have developed strategies to deal with problems as they arise, ways to suppress conflict, etc. (Morgan and Rindfuss, 1985; Thomson and Colella, 1992). With the longer years of living together, "marital-specific capital" also increases, making divorce more costly (Becker, Landes and Michael, 1977).

\section{Place of residence}

Higher risk of divorce is usually found in urban areas (Lyngstad, 2006; Muszynska, 2006, 2006a). This incidence reflects more liberal social norms and lower stigmatization of divorcees as well as less difficulty in making divorce official. The marriage market is larger in urban areas, and singles have more opportunities to find an alternative partner. The facts that young couples dissolve their union more often than older ones and that the urban population is typically younger than the rural also contribute to the explanation of higher divorce rate in cities and other urban areas (Moskoff, 1983). 


\section{Religion}

Religion, as it provides a source of more traditional family values and higher moral commitment, has been shown to exert a notable influence on marital stability (Gelissen, 2003; Call and Heaton, 1997; Hoem and Hoem, 1992). Research by Call and Heaton (1997) indicates that more frequent church attendance leads to lower risk of divorce.

The impact of religious affiliation on marital stability seems to be less significant than religious activity and it is generally decreasing. Earlier research, for example, found that Catholic unions were less likely to be terminated by divorce than Protestant counterparts, which was explained by the strict stand of the Catholic Church against divorce; and more recent studies report a convergence in the risk of divorce among Protestant and Catholic unions (see a review of related research by Lehrer, 1996). However, when compared to those with no religious affiliation, Catholics, Protestants, Muslims and persons belonging to other religions are found to hold less tolerant attitudes about divorce (Gelissen, 2003) and to experience lower divorce risk (de Graaf and Kalmijn, 2006).

\section{Calendar period}

We believe that it is very important to include a period perspective in the analysis. The importance of period perspective is emphasized in a number of other studies (Lutz, Wils and Nieminen, 1991; Kravdal, 1988; Andersson, 1997). Variation of divorce risk over calendar time reflects both modifications in divorce legislation as well as broader changes in the socio-economic and cultural context.

\section{Data and methods}

The analysis is based on the Russian Generations and Gender Survey data containing full histories of union formation and dissolution as well as of childbearing. The survey was conducted in June through August of 2004. Since we are not concerned with a comparison of men and women in this study, we restrict our sample to first-time married women.

The dependent variable in our study is the transition to legal divorce. The process time (the basic time factor) is the time elapsed from entry into first marriage until divorce, measured in months. Observations are censored in two situations: at the date of interview, if there is no event, and at the death of a partner, when marriage ends due to this reason. The total number of cases included in the analysis is 5599 (from an initial dataset of 11,261). The number of events is 1581. Table 2 categorizes all the cases that had to be excluded from the analysis. 
Table 2: Number of included and excluded cases in the analysis

\begin{tabular}{l|l}
\hline Number of cases in the initial dataset & 11261 \\
Reasons for exclusions: & 4223 \\
Men & 1400 \\
Never-married women & 2 \\
First marriage before the respondent's date of birth & 9 \\
First marriage before age 15 & 19 \\
Missing information either on date of separation or on its cause (which may be \\
$\begin{array}{l}\text { either divorce or death of the husband) } \\
\text { Divorce before first marriage }\end{array}$ \\
\hline $\begin{array}{l}\text { Number of cases in the analysis } \\
\text { Number of events }\end{array}$ & 9 \\
\hline
\end{tabular}

Source: Russian GGS, author’s calculations.

We apply a piecewise constant event history model in our analysis, which assumes that hazard rates are constant in each segment of the basic time factor but can vary across them (for more details, see Blossfeld and Rohwer, 2001). In our analysis, we cut the baseline into eight segments. The first five segments are one-year intervals, the next two are two-year intervals and the last one covers the rest of the time axis. The cut points are as follows: 1, 2, 3, 4, 5, 7, 9 and 10+. Results are presented in a form of exponentiated coefficients, which are interpreted as relative risks in the text.

In order to reduce the bias related to the sampling procedure, Kish weights have been applied in the analysis (for a more detailed report about the sampling procedure, see Kosolapov and Zakharov, 2005).

\section{Covariates}

We now turn to the description of variables. We include a set of time-constant and time-varying covariates. For a complete list of variables and the distribution of exposures for each of them, see Table 4.

The key independent variable is motherhood status at marriage, comprising three groups of women. The first group of women includes those who had premarital births and thus already had child(ren) at the entry into first marriage. We do not distinguish whether the husband is the biological father of the child(ren) or not, which is beyond the scope of this study. The second group consists of women who married following conception, i.e. they were pregnant at marriage. The third group encompasses women who were childless at marriage. Based on the findings of previous studies, we expect that both premarital conception and premarital birth increase the risk of marital disruption, compared to women who were not pregnant and had no child at marriage.

The way we define the category of women "pregnant at marriage" is connected to our objective to capture marriages induced by conception, i.e. the so-called "shotgun" marriages, and their stability. We consider that during the first month or two of the pregnancy, a woman might not be aware of or completely sure about her status. When the pregnancy is confirmed, the couple usually needs some time to decide if they want to keep the baby. Despite decreasing rates, induced abortions are still relatively frequent in Russia, and women normally are allowed to have an abortion within the 
first 12 weeks of pregnancy (Avdeev, Blum and Troitskaya, 1995). So this time might be regarded as a period of consideration. Once the couple decides to marry, the wedding arrangements also take some time. Therefore, we make an assumption that the highest probability of shotgun marriage is in the cases when marriage is registered in the fourth month of pregnancy or later. Consequently, a premaritally conceived child is expected to be born during the first five months of marriage. Earlier conceptions increase the probability of situations other than a pregnancy-induced marriage. For example, the couple may have stopped preventing conception before the anticipated wedding, or the woman may not even have been aware of her very early pregnancy at marriage. Correspondingly, in our study, conceptions which result in childbirth after six or more months of marriage, are assumed to be marital. Table 3 gives the distribution of the sample by motherhood status at marriage as well as other related basic statistics.

In other studies, premarital conception is usually considered as such if the child is born during the first seven or eight months of marriage. However, we want not only to see how the timing of birth is associated with the stability of marital union, but also to test whether marriages seemingly induced by pregnancy run a higher divorce risk than those formed without anticipation of childbirth. Before deciding to take the interval of five months of marriage as defining the time when premaritally conceived children are born, we developed several experimental models using different intervals from a range of 0-8 months. The effect was essentially independent of the interval. At the same time, we found proof that the first five months of marriage are crucial in terms of the significance of this effect.

Table 3: Simple statistics of the main covariate

\begin{tabular}{lcccc}
\hline & $\begin{array}{c}\text { N of women in } \\
\text { exposures }\end{array}$ & Exposures & Events & Rate \\
\hline Child(ren) at marriage & 548 & 8841 & 121 & 0.014 \\
Pregnant at marriage & 569 & 9150 & 149 & 0.016 \\
No child at marriage & 4482 & 88267 & 1106 & 0.013 \\
Total & 5599 & 106258 & 1376 & 0.013 \\
\hline Source Russian GGS, author's calculations.
\end{tabular}

Source: Russian GGS, author’s calculations.

Another covariate included in our analysis is a factor combining women's parity and age of the youngest child. It is a time-varying covariate describing the impact of children on the risk of marital disruption. We distinguish between parity 0 (no child), parity 1, parity 2 and parity $3+$. The age of the youngest child is categorized by age group: aged 0-3 years (very young children), 4-6 (children of preschool age) and 7+. Parity 0 is included as a separate category in the combination factor. Following the theoretical discussion provided earlier, we hypothesize that childless women run the highest risk of divorce and that the risk of marital breakdown increases as the youngest child grows older.

Divorce risk for women with different motherhood status at marriage is additionally controlled for age at marriage. We set up the following age groups: 15-18, 19-22, 2325, 26-29 and 30+. According to our expectations, the risk of divorce should be negatively related to the age at marriage. 
We have also included as a covariate parental divorce, previously found to be associated with the risk of marital dissolution. It comprises two categories: "yes, parents divorced" and "no, parents never divorced." We expect that the experience of parental divorce increases the risk of marital dissolution.

Table 4: Distribution of exposures for variables included in the analysis

\begin{tabular}{|c|c|c|c|}
\hline \multicolumn{2}{|l|}{ Time-constant covariates: } & \multicolumn{2}{|l|}{ Time-varying covariates: } \\
\hline & $\%$ & & $\%$ \\
\hline Motherhood status at marriage & & Duration of marriage & \\
\hline Child(ren) at marriage & 8.8 & $1^{\text {st }}$ year & 11.1 \\
\hline Pregnant at marriage & 9.4 & $2^{\text {nd }}$ year & 9.6 \\
\hline \multirow[t]{2}{*}{ No child at marriage } & 81.8 & $3^{\text {rd }}$ year & 8.8 \\
\hline & & $4^{\text {th }}$ year & 10.5 \\
\hline Age at 1st marriage & & $5^{\text {th }}$ year & 9.2 \\
\hline $15-18$ & 7.2 & 6-7 years & 12.7 \\
\hline $19-22$ & 52.6 & 8-9 years & 11.0 \\
\hline $23-26$ & 27.9 & $10+$ years & 27.1 \\
\hline $27-29$ & 6.2 & & \\
\hline \multirow[t]{2}{*}{$30+$} & 6.1 & Parity and age of youngest child & \\
\hline & & Parity 0 & 16.4 \\
\hline Parents ever divorced & & Parity 1 , aged $0-3$ & 22.7 \\
\hline Yes & 12.4 & aged 4-6 & 12.1 \\
\hline No & 86.3 & aged $7+$ & 10.6 \\
\hline \multirow[t]{2}{*}{ Missing } & 1.3 & Parity 2, aged 0-3 & 12.6 \\
\hline & & aged $4-6$ & 7.6 \\
\hline Place of residence & & aged $7+$ & 10.1 \\
\hline Moscow, St. Petersburg & 8.6 & Parity $3+$, aged $0-3$ & 3.4 \\
\hline Other oblast (regional) center & 28.5 & aged $4-6$ & 1.8 \\
\hline Other urban area & 34.4 & aged 7+ & 2.8 \\
\hline \multirow[t]{2}{*}{ Rural area } & 28.6 & & \\
\hline & & Period & \\
\hline Religion group & & $<1960$ & 8.3 \\
\hline Orthodox & 81.3 & $1960-1964$ & 7.9 \\
\hline Muslim & 4.3 & 1965-1969 & 8.4 \\
\hline \multirow[t]{7}{*}{ Other/missing } & 14.4 & $1970-1974$ & 9.4 \\
\hline & & 1975-1979 & 10.7 \\
\hline & & 1980-1984 & 12.2 \\
\hline & & 1985-1989 & 12.8 \\
\hline & & 1990-1994 & 12.2 \\
\hline & & 1995-1999 & 10.0 \\
\hline & & $2000-2004$ & 8.0 \\
\hline
\end{tabular}

Source: Russian GGS, author’s calculations.

Further, we add place of residence. This covariate consists of three categories. The first category covers the two biggest cities and most important oblast (regional) centers of Russia - Moscow and St. Petersburg. The second category contains other oblast centers. The third one, which is labeled as "other urban area," includes towns and other urban-type communities. The fourth category is "rural area," which is 
originally defined as such in the dataset. Based on the literature, we anticipate the highest risk of divorce to be found in most urbanized areas.

We control for religion group, aiming to examine divorce risk variation by religious composition in Russia. We distinguish between Orthodox Christians and Muslims. Orthodox believers constitute the largest religious community. Muslims are much fewer in number; nevertheless they are the second largest religious community in Russia. The third category includes other or missing cases as well as those with no religious affiliation. Unfortunately, the latter group was too small to make a separate category - there were fewer than 10 cases. We include missing cases in our models because they comprise almost 13 percent of all cases.

Another time-varying covariate is calendar period. The first category covers the years before 1960 . We divide the middle three categories into five-year intervals. The last category comprises the years 2000-2004, but one should take into account that the year 2004 is not complete; it includes only the months up to the date of interview. We expect that our results will reflect to some extent the observed divorce trends presented in Figure 1.

\section{Results}

Table 5 reports the results from the piecewise constant event history models on transition to divorce in Russia. Each of seven models includes an additional parameter, and we can see that Model 7, containing all covariates, demonstrates the best model fit. Therefore, we focus on Model 7 in our further analysis.

Our results support the findings of previous research as well as our expectations regarding the effect of premarital conception on the stability of subsequent marriage. The risk of divorce for women whose marriage was essentially induced by pregnancy is significantly higher than for women who were childless at marriage. Premarital conception increases the risk of marital dissolution by 22 percent, and a premarital child does so by 54 percent.

As far as the effect of parity is considered, we find that childless women run the highest risk of divorce. For one-child mothers, it is slightly lower than for the childless. The lowest risk of marital disruption is observed among women with two children. Risk changes at subsequent parities do not seem to be substantial. Thus, the arrival of the second child has a significant positive effect on the stability of marriage, but additional children do not bring any further increase in this effect. The age of the youngest child seems to be an important predictor of divorce too; however, a statistically significant and really strong effect has been found only for first-borns. A general observation is that children decrease the chance of marital breakup at the time they arrive in the family and when they are still very young. During the child's preschool years (age 4-6), the union is at greatest risk in terms of divorce, especially if it has only one child. 
Table 5: Relative risks of divorce, first time married women

\begin{tabular}{|c|c|c|c|c|c|c|c|}
\hline & Model 1 & Model 2 & Model 3 & Model 4 & Model 5 & Model 6 & Model 7 \\
\hline \multicolumn{8}{|l|}{ Duration of marriage } \\
\hline $1^{\text {st }}$ year & 1 (ref.) & 1 (ref.) & 1 (ref.) & 1 (ref.) & 1 (ref.) & 1 (ref.) & 1 (ref.) \\
\hline $2^{\text {nd }}$ year & $1.49 * * *$ & $1.48^{* * *}$ & $1.58 * * *$ & $1.63 * * *$ & $1.66 * * *$ & $1.65^{* * *}$ & $1.65^{* * *}$ \\
\hline $3^{\text {rd }}$ year & $1.50 * * *$ & $1.48 * * *$ & $1.68^{* * *}$ & $1.74 * * *$ & $1.83^{* * *}$ & $1.81^{* * *}$ & $1.81^{* * *}$ \\
\hline $4^{\text {th }}$ year & $1.48 * * *$ & $1.45^{* * *}$ & $1.69 * * *$ & $1.77 * * *$ & $1.85 * * *$ & $1.83^{* * *}$ & $1.83 * * *$ \\
\hline $5^{\text {th }}$ year & $1.40 * *$ & $1.37 * *$ & $1.57 * * *$ & $1.67 * * *$ & $1.75 * * *$ & $1.74 * * *$ & $1.74 * * *$ \\
\hline 6-7 years & 1.05 & 1.02 & $1.32 * *$ & $1.42 * *$ & $1.48 * *$ & $1.48^{* *}$ & $1.47 * *$ \\
\hline 8-9 years & $0.75^{* *}$ & $0.72 * *$ & 1.21 & 1.29 & $1.37^{*}$ & $1.35^{*}$ & $1.35^{*}$ \\
\hline $10+$ years & $0.46^{* * *}$ & $0.39 * * *$ & 0.78 & 0.86 & 0.93 & 0.91 & 0.91 \\
\hline \multicolumn{8}{|l|}{$\begin{array}{l}\text { Motherhood status at } \\
\text { marriage }\end{array}$} \\
\hline Child(ren) at marriage & 1.04 & 1.01 & $1.30 * *$ & $1.52 * * *$ & $1.52 * * *$ & $1.57 * * *$ & $1.54^{* * *}$ \\
\hline Pregnant at marriage & $1.21^{* *}$ & 1.16 & $1.28 * * *$ & $1.24 * *$ & $1.24 * *$ & $1.23^{* *}$ & $1.22 * *$ \\
\hline No child at marriage & 1 (ref.) & 1 (ref.) & 1 (ref.) & 1 (ref.) & 1 (ref.) & 1 (ref.) & 1 (ref.) \\
\hline \multicolumn{8}{|l|}{ Period } \\
\hline$<1960$ & & $0.61 * *$ & $0.62 * *$ & $0.60 * *$ & $0.62 * *$ & $0.62 * *$ & $0.61 * *$ \\
\hline $1960-1964$ & & 1 (ref.) & 1 (ref.) & 1 (ref.) & 1 (ref.) & 1 (ref.) & 1 (ref.) \\
\hline $1965-1969$ & & 1.30 & 1.26 & 1.26 & 1.21 & 1.21 & 1.22 \\
\hline $1970-1974$ & & $1.82 * * *$ & $1.78 * * *$ & $1.74 * * *$ & $1.76^{* * *}$ & $1.74^{* * *}$ & $1.75^{* * *}$ \\
\hline $1975-1979$ & & $1.98 * * *$ & $1.94 * * *$ & $1.91 * * *$ & $1.90^{* * *}$ & $1.88^{* * *}$ & $1.89 * * *$ \\
\hline 1980-1984 & & $1.70^{* * *}$ & $1.70 * * *$ & $1.68 * * *$ & $1.67 * * *$ & $1.66^{* * *}$ & $1.68 * * *$ \\
\hline $1985-1989$ & & $1.45^{* *}$ & $1.53^{* * *}$ & $1.52 * * *$ & $1.50 * *$ & $1.49 * *$ & $1.52 * *$ \\
\hline 1990-1994 & & $1.80^{* * *}$ & $1.83^{* * *}$ & $1.78 * * *$ & $1.73^{* * *}$ & $1.75^{* * *}$ & $1.78 * * *$ \\
\hline 1995-1999 & & $2.11^{* * *}$ & $2.05^{* * *}$ & $1.98 * * *$ & $1.88^{* * *}$ & $1.90^{* * *}$ & $1.94 * * *$ \\
\hline 2000-2004 & & $2.10^{* * *}$ & $2.00 * * *$ & $1.94 * * *$ & $1.85^{* * *}$ & $1.85^{* * *}$ & $1.89 * * *$ \\
\hline \multicolumn{8}{|l|}{$\begin{array}{l}\text { Parity and age of } \\
\text { youngest child }\end{array}$} \\
\hline Parity 0 & & & $3.25 * * *$ & $3.60 * * *$ & $3.75^{* * *}$ & $3.56 * * *$ & $3.55 * * *$ \\
\hline Parity 1 , aged $0-3$ & & & $2.88 * * *$ & $2.97 * * *$ & $3.01 * * *$ & $2.88 * * *$ & $2.86 * * *$ \\
\hline aged 4-6 & & & $3.59 * * *$ & $3.65 * * *$ & $3.77 * * *$ & $3.56 * * *$ & $3.52 * * *$ \\
\hline aged $7+$ & & & $2.40 * * *$ & $2.57 * * *$ & $2.62 * * *$ & $2.45^{* * *}$ & $2.41 * * *$ \\
\hline Parity 2, aged 0-3 & & & 1 (ref.) & 1 (ref.) & 1 (ref.) & 1 (ref.) & 1 (ref.) \\
\hline aged 4-6 & & & 0.98 & 0.98 & 0.98 & 0.98 & 0.97 \\
\hline aged $7+$ & & & $1.38^{*}$ & $1.41 *$ & $1.45^{*}$ & $1.45^{*}$ & $1.42 *$ \\
\hline Parity $3+$, aged $0-3$ & & & 1.09 & 1.04 & 1.01 & 1.05 & 1.10 \\
\hline aged 4-6 & & & 1.46 & 1.39 & 1.43 & 1.49 & 1.53 \\
\hline aged 7+ & & & $0.61 *$ & $0.60 *$ & $0.62 *$ & 0.65 & 0.65 \\
\hline \multicolumn{8}{|l|}{ Age at 1st marriage } \\
\hline $15-18$ & & & & $1.94 * * *$ & $1.88^{* * *}$ & $2.00 * * *$ & $2.00 * * *$ \\
\hline $19-22$ & & & & $1.47 * * *$ & $1.44 * * *$ & $1.50 * * *$ & $1.49 * * *$ \\
\hline $23-26$ & & & & 1 (ref.) & 1 (ref.) & 1 (ref.) & 1 (ref.) \\
\hline $27-29$ & & & & 1.18 & 1.19 & 1.14 & 1.15 \\
\hline $30+$ & & & & $0.69 * *$ & $0.70^{* *}$ & $0.65 * * *$ & $0.65 * * *$ \\
\hline \multicolumn{8}{|l|}{ Parents ever divorced } \\
\hline Yes & & & & & $1.53^{* * *}$ & $1.49 * * *$ & $1.46^{* * *}$ \\
\hline No & & & & & 1 (ref.) & 1 (ref.) & 1 (ref.) \\
\hline \multicolumn{8}{|l|}{ Place of residence } \\
\hline Moscow, St. Petersburg & & & & & & $1.59 * * *$ & $1.58 * * *$ \\
\hline $\begin{array}{l}\text { Other oblast (regional) } \\
\text { center }\end{array}$ & & & & & & 1 (ref.) & 1 (ref.) \\
\hline Other urban area & & & & & & $0.85 * *$ & $0.85 * *$ \\
\hline Rural area & & & & & & $0.70^{* * *}$ & $0.71 * * *$ \\
\hline \multicolumn{8}{|l|}{ Religion group } \\
\hline Orthodox & & & & & & & 1 (ref.) \\
\hline Muslim & & & & & & & $0.46 * * *$ \\
\hline Other/missing & & & & & & & 0.98 \\
\hline \multicolumn{8}{|l|}{ Model fit } \\
\hline Initial LL & -5008 & -5008 & -5008 & -5008 & -4921 & -4921 & -4921 \\
\hline Final LL & -4826 & -4783 & -4681 & -4642 & -4544 & -4503 & -4493 \\
\hline
\end{tabular}

Source: Russian GGS; author's calculations; ${ }^{* * *} \mathrm{p}<0.01,{ }^{* *} \mathrm{p}<0.05,{ }^{*} \mathrm{p}<0.1$. 
The risk of divorce is negatively related to the age at marriage. In 2004, the mean age at first marriage for women in Russia was 23.3 years (Naselenie Rossii, 2006). Divorce among women who married at age 15-18 was twice as frequent as among women who married at age 23-26. The lowest risk of marital dissolution was found for women who entered into first marriage at age 30 and older.

Our analysis replicates the results of prior studies about the negative impact of parental divorce on the stability of children's marriages. According to our estimates, experience of parental divorce increases the risk of marital dissolution by 46 percent compared to those whose parents never divorced.

As for the effect of duration of marriage, we find that the risk of marital breakup sharply increases during the first several years. The maximum risk is reached in the fourth year of marriage and then gradually declines with every subsequent year.

The urbanization level of the place of residence also exerts a major influence of the risk of divorce. The higher the level of urbanization, the higher is the risk of divorce. Women living in Moscow and St. Petersburg are most prone to dissolve their marital unions. Divorce in the latter group of women is 58 percent higher than among women from other oblast centers in Russia. The lowest risk of marital dissolution is observed in rural areas; it is 29 percent lower compared to oblast centers other than Moscow and St. Petersburg (reference category).

For religious affiliation, we are mainly able to compare Orthodox Christians and Muslims. Our results show that the risk of divorce among Muslim women is 54 percent lower than among members of the Orthodox Church.

Regarding the effect of calendar period, our results reflect the observed trends in divorce rates. In line with Russian divorce statistics, we find a steep rise in divorce risk from the beginning of our observation ${ }^{2}$ until the late 1970s. Then divorce risk slightly levels off until a further increase in the decade 1990-1999, after which it declines again. The real trend is more dynamic in the 1990s; however, the five-year intervals that we use for our analysis do not capture all the ups and downs.

\section{Interaction models}

Additionally, we have created a model including a combination factor of motherhood status at marriage and parity combined with age of the youngest child. Figure 3 shows the interaction between the two covariates, while the whole model is provided in Appendix 1. Due to small sample sizes, we made broader categories for the parity factor and instead of the category "parity 3+" we used a category "parity 2+". However, the picture has not been changed much by this adjustment as according to our estimations, divorce risks at parities 2 and $3+$ are rather similar.

\footnotetext{
${ }^{2}$ Considering that the oldest women included in our analysis were born in 1923, our observation starts in 1938, i.e. when they turn 15 years of age.
} 
Figure 3: Relative risks of divorce by motherhood status at marriage and parity and age of the youngest child; first-time married women

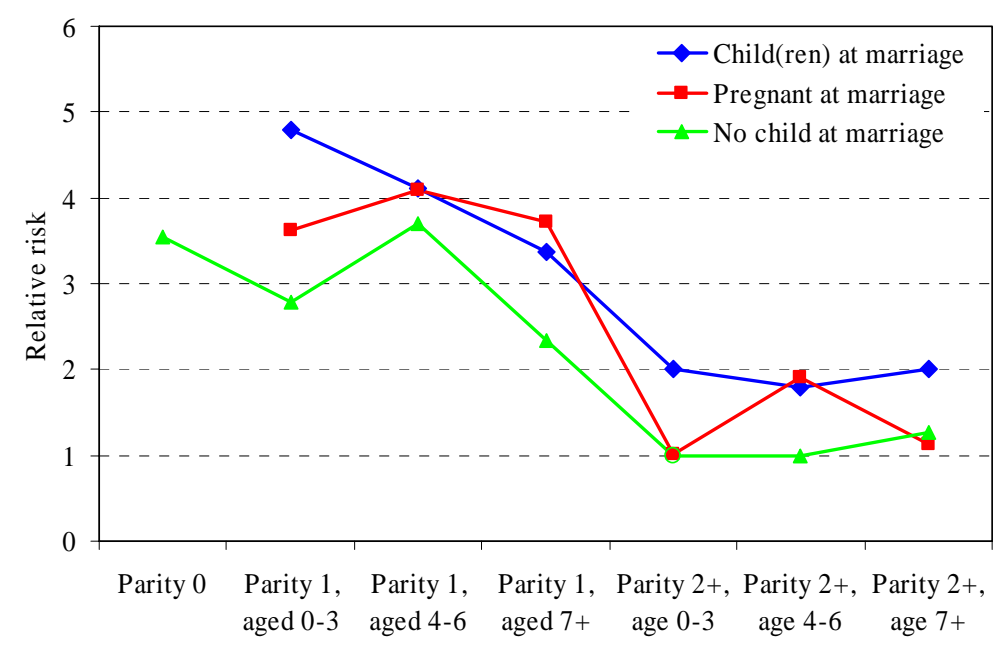

Source: Russian GGS; author's calculations.

Note: controlled for duration of marriage (baseline), calendar period, age at marriage, parental divorce, place of residence, and religion group.

As can be seen from Figure 3, the elevated risk of divorce for women with premarital children is observed at all parities and it is independent of the age of the youngest child. As for women who married while pregnant, we see a very similar association, but not at second and higher parities. They face a very high probability of divorce at parity 1 , but the birth of the second and subsequent children seemingly brings these women's risk of divorce closer to that of women with no child at marriage.

By creating a combination model that includes motherhood status and calendar period, we expected to obtain a better understanding of how the effect of premarital conception on the propensity to divorce has been changing over time. Figure 4 presents the interaction between motherhood status at marriage and calendar time (for the whole model, see Appendix 2). Our results show that the divorce risk for women pregnant at marriage was extremely high during the 1970s (about double that for women with no child at marriage). However, later on and particularly since the beginning of the 1990s, the trends converge for both groups of women. 
Figure 4: Relative risks of divorce by motherhood status at marriage and calendar period; first time married women

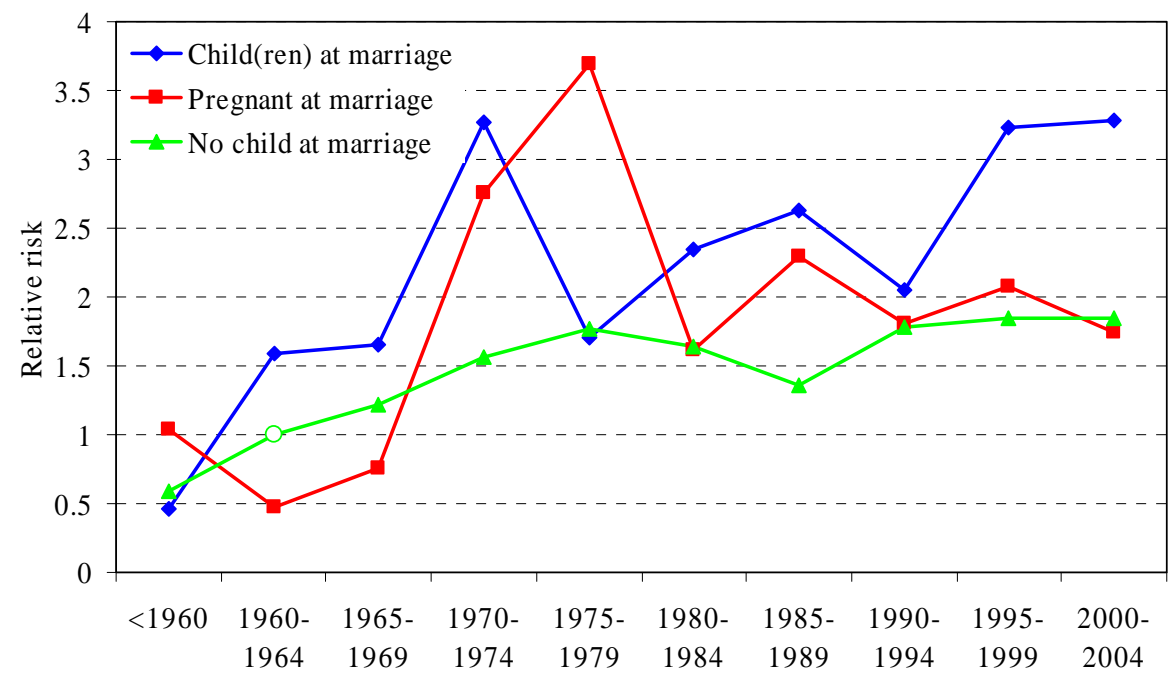

Source: Russian GGS; authors' calculations.

Note: controlled for duration of marriage (baseline), parity and age of the youngest child, age at marriage, parental divorce, place of residence, and religion group.

\section{Discussion of results and conclusions}

Russia's population has for long been characterized by a high divorce rate. It has one of the highest divorce indicators in Europe. To our knowledge, however, very few studies have attempted not only to describe, but also to explain the Russian pattern of divorce. Our analysis has not come very far in reaching the explanation as the causes behind the observed trends are many and highly intertwined. Nevertheless, this study does contribute further to our understanding of divorce in Russia as well as revealing areas requiring further investigation.

Non-marital conception is another phenomenon on which we have focused in this study. Despite the societal disapproval, sexual relations outside of marriage have been practiced in Russia for a long time, and unintentional pregnancies due to limited knowledge and access to contraception have been relatively frequent. Consequently, many marriages have been contracted with the purpose of legitimating births. The proportion of children born outside marriage was low until the late 1980s. Later, along with the changing social norms and attitudes, came an increase in non-marital births, an increasing share of which occurs in cohabiting unions. Nevertheless, as the sources of data cited earlier in the paper suggest, the proportion of conceptions preceding marriage remains relatively high in Russia. Many couples still prefer to marry after learning about the (expected or unexpected) pregnancy.

Our aim in this study was to examine if and how premarital conception affects the stability of subsequent marriage. As a matter of fact, our results provide further evidence of a lower stability of marriages induced by pregnancy. Premarital conception increases the risk of divorce in subsequent marriage and premarital birth 
raises the risk even higher. We also would not reject the possibility that an increasing incidence of shotgun marriages was among the set of factors that caused the rise in divorce rates in the 1960s through the 1970s. Our estimates show a highly elevated risk of divorce both among women pregnant at marriage and women with child(ren) at marriage for this period. As for the most recent period, we believe that the converging trends in terms of divorce risk for pregnancy-induced marriages and marriages contracted without anticipated childbirth are linked to the spread and increasing acceptance of informal cohabitation. Cohabiting couples are more likely to marry and to plan children than singles (Musick, 2007); thus, marriages following conception might not be forced to such an extent as they were before. These findings, however, need further elaboration.

The effect of parenthood largely conforms to the results of previous studies. We find that having children reduces the risk of marital dissolution and that divorce is most likely to occur among childless unions. However, having more children does not necessarily lead to lower divorce risk. The arrival of the second child has the strongest positive impact on marital stability, and the contribution of subsequent children is not that significant. Parity similarly affects both women who married after premarital conception or premarital birth and those who married childless.

There is no consensus from previous research regarding the effect of the age of children. In the case of Russia, the age of the youngest child has a great impact on the propensity to divorce, but it mainly concerns first-borns. This association is not linear. According to our results, the risk of divorce considerably decreases upon the arrival of a child in the family. Then the risk increases as the child grows and declines again when the child starts school.

For the effect of other divorce determinants, we would like to draw attention to the following findings:

- Early marriage increases the probability of divorce and marrying at an older age contributes to marital stability.

- Parental divorce has a detrimental effect on children's marriages. Children from divorced families are more prone to divorce than children from stable families.

- For the association between the duration of marriage and divorce risk, the risk of marital breakup increases during the first four years and then gradually declines.

- Living in highly urbanized areas increases the risk of divorce. The higher the level of urbanization, the higher are the chances of marital dissolution. The highest probability of divorce is found in Moscow and St. Petersburg.

- Divorce is more frequent among the Orthodox than among the Muslim population.

\section{Acknowledgements}

I would like to thank Michaela Kreyenfeld for her helpful suggestions and continuous encouragement. For valuable comments, I am very grateful to Vladimir Shkolnikov, Evgueni Andreev and Jan Hoem. For language editing, I wish to thank Susann Backer. 


\section{References}

1. Andersson G. (1997). The Impact of Children on Divorce Risks of Swedish Women. European Journal of Population, No. 13, pp. 109-145.

2. Amato P.R. (1996). Explaining the Intergenerational Transmission of Divorce. Journal of Marriage and the Family, Vol. 58, No. 3 (Aug., 1996), pp. 628-640.

3. Avdeev A., Blum A., Troitskaya I. (1995). The History of Abortion Statistics in Russia and the USSR from 1900 to 1991. Population: An English Selection, Vol. 7. (1995), pp. 39-66.

4. Avdeev A., Monnier A. (2000). Marriage in Russia: A Complex Phenomenon Poorly Understood. Population: An English Selection, Vol. 12 (2000), pp. 7-49.

5. Becker G.S., Landes E.M., Michael R.T. (1977). An Economic Analysis of Marital Instability. The Journal of Political Economy, Vol. 85, No. 6. (Dec., 1977), pp. 11411188.

6. Blossfeld H.P., Rohwer G. (2002). Techniques of Event History Modeling: New Approaches to Causal Analysis. Mahwah, New Jersey and London: Lawrence Erlbaum Associates, Inc., 310 p.

7. Call V.R.A., Heaton T.B. (1997). Religious Influence on Marital Stability. Journal for the Scientific Study of Religion, Vol. 36, No. 3. (Sep., 1997), pp. 382-392.

8. Clarke L., Berrington, A. (1999). Socio-demographic predictors of divorce; in: Simons, J. (ed.) High Divorce Rates: The State of the Evidence on Reasons and Remedies: Reviews of Evidence on the Causes of Marital Breakdown and the Effectiveness of Policies and Services Intended to Reduce its Incidence. Research Series, Vol. 1, Lord Chancellor's Department, London.

9. Council of Europe (2006). Recent Demographic Developments in Europe. Strasbourg: Council of Europe Publishing.

10. Darsky L., Scherbov S. (1995). Marital Status Behaviour of Women in the Former Soviet Republics. European Journal of Population, Vol. 11, pp. 31-62.

11. De Graaf P.M., Kalmijn M. (2006). Change and Stability in the Social Determinants of Divorce: A Comparison of Marriage Cohorts in the Netherlands. European Sociological Review, Vol. 22, No. 5, pp. 561-572.

12. Gelissen J.P.T.M. (2003). Cross-National Differences in Public Consent to Divorce: Effects of Cultural, Structural and Compositional Factors; in Arts W., Halman L.C.J.M. and Hagenaars J.A.P. (Eds.) The Cultural Diversity of European Unity: Findings, Explanations and Reflections from the European Values Study. Leiden: Brill Academic Publishers, pp. 339-370.

13. Generations \& Gender Contextual Database (2006). http://www.demogr.mpg.de

14. Hoem J. (1997). The Impact of the First Child on Family Stability. Stockholm Research Report in Demography, No. 119. Stockholm: Stockholm University, 13 p.

15. Hoem J. (2000). Systematic Patterns of Zero Exposures in Event-History Analysis. Sociological Methodology, Vol. 30, (2000), pp. 237-259.

16. Hoem B., Hoem J. (1992). The Disruption of Marital and Non-Marital Unions in Contemporary Sweden; in: Trusell J., Hankinson R. and Tilton J. (Eds.) Demographic Applications of Event History Analysis. Oxford: Clarendon Press, pp. 61-93.

17. Ilyina I. (1994). Marital-Status Composition of the Soviet Population; in W. Lutz, S. Scherbov and A. Volkov (Eds.) Demographic Trends and Patterns in the Soviet Union before 1991. London and New York: Routledge, pp. 167-183.

18. Ivanova E., Mikheeva A. (1998). Vnebrachnoe materinstvo v Rossii [Non-marital Motherhood in Russia]. Naselenie i obtshestvo, No. 28, July.

19. Kosolapov M., Zakharov S. (2005). The Report on Response Rate in Russian GGS. Rostock, Max Planck Institute for Demographic Research, 25 p.

20. Kravdal Ø. (1988). The Impact of First-Birth Timing on Divorce: New Evidence from a Longitudinal Analysis Based on the Central Population Register of Norway. European Journal of Population, Vol. 3, No. 3(4) (July, 1988), pp. 247-269. 
21. Lehrer E.L (1996). The Role of the Husband's Religious Affiliation in the Economic and Demographic Behavior of Families. Journal for the Scientific Study of Religion, Vol. 35, No. 2. (Jun., 1996), pp. 145-155.

22. Lillard L.A., Waite L.J. (1993). A Joint Model of Marital Childbearing and Marital Disruption. Demography, Vol. 30, No. 4 (Nov., 1993), pp. 653-681.

23. Liu G. (2002). How Premarital Children and Childbearing in Current Marriage Influence Divorce of Swedish Women in Their First Marriages. Demographic Research, Vol. 7, Article 10, pp. 389-406.

24. Lutz W., Wils A.B., Nieminen M. (1991). The Demographic Dimensions of Divorce: The Case of Finland. Population Studies, No. 45, pp. 437-453.

25. Lyngstad T.H. (2004). The Impact of Parents' and Spouses' Education on Divorce Rates in Norway. Demographic Research, Vol. 10, Article 5, pp 121-142, published 15 April 2004.

26. Lyngstad T.H. (2006). Why Do Couples with Highly Educated Parents Have Higher Divorce Rates? European Sociological Review, Vol. 22, No. 1 (Feb., 2006), pp. 49-60.

27. Morgan S.Ph., Rindfuss R.R. (1985). Marital Disruption: Structural and Temporal Dimensions. The American Journal of Sociology, Vol. 90, No. 5 (Mar., 1985), pp. 10551077.

28. Moskoff, W. (1983). Divorce in the USSR. Journal of Marriage and the Family, Vol. 45, No. 2 (May, 1983), pp. 419-425.

29. Murphy M.J. (1985). Demographic and Socio-economic Influences on Recent British Marital Breakdown Patterns. Population Studies, Vol. 39, Issue 3, pp. 441-460.

30. Musick K. (2007). Cohabitation, Non-Marital Childbearing, and the Marriage Process. Demographic Research, Vol. 16, Article 9, published 20 April 2007, pp. 249-286.

31. Muszynska M. (2006a).Woman's Employment and Union Disruption in a Changing Socio-Economic Context: the Case of Russia. MPIDR Working Paper, WP 2006-027, August 2006, 28 p.

32. Muszynska M. (2006b). Migration and Union Dissolution in a Changing Socio-Economic Context: the Case of Russia. MPIDR Working Paper, WP 2006-032, October 2006, 22 p.

33. Naselenie Rossii 2003-2004 [Russian Population 2003-2004] (2006). Moskva, 356 p.

34. Philipov D., A. Jasilioniene (2007). Union formation and fertility in Bulgaria and Russia: a life table description of recent trends. MPIDR Working Paper, WP 2007-005, February 2007, 59 p.

35. Sanjian A.S. (1991). Social Problems, Political Issues: Marriage and Divorce in the USSR. Soviet Studies, Vol. 43, No. 4, pp. 629-649.

36. Scherbov S., van Vianen H. (1999). Marital and Fertility Careers of Russian Women Born between 1910 and 1934. Population and Development Review, Vol. 25, No. 1 (Mar., 1999), pp. 129-143.

37. Scherbov S., van Vianen H. (2001). Marriage and Fertility in Russia of Women Born between 19000 and 1960: A Cohort Analysis. European Journal of Population, Vol. 17, pp. 281-294.

38. Scherbov S., van Vianen H. (2004). Marriage in Russia. A Reconstruction. Demographic Research, Vol. 10, Article 2, published 26 February 2004, pp. 27-60.

39. Teachman J.D., Polonko K.A. (1990). Cohabitation and Marital Stability in the United States. Social Forces, Vol. 69, No. 1 (Sep., 1990), pp. 207-220.

40. Thomson E., Colella U. (1992). Cohabitation and Marital Stability: Quality or Commitment? Journal of Marriage and the Family, Vol. 54, No. 2. (May, 1992), pp. 259267.

41. Thornton A. (1991). Influence of the Marital History of Parents on the Marital and Cohabitational Experiences of Children. The American Journal of Sociology, Vol. 96, No. 4. (Jan., 1991), pp. 868-894.

42. Tolts M., Antonova O., Andreev E. (2005). Rozhdaemost i transformaciia instituta sem'i v sovremennoi Rossii [Fertility and Transformation of the Institution of Family in Contemporary Russia]. Voprosy statistiki (Moscow), No. 7, pp. 51-60. 
43. Tolts M., Antonova O., Andreev E. (2006). Extra-Marital Conceptions in Contemporary Russia's Fertility. Paper presented at the European Population Conference 2006, Liverpool, the UK, June 21-24, 2006.

44. Troitskaya I., Andersson G. (2007). Transition to Modern Contraception in Russia: Evidence from the 1996 and 1999 Women's Reproductive Health Surveys. MPIDR Working Paper, WP 2007-010, February 2007, 18 p.

45. Vishnevsky A.G. (1996). Family, Fertility, and Demographic Dynamics in Russia: Analysis and Forecast; in J. DaVanzo and G. Farnsworth (Eds.) Russia’s Demographic “Crisis”. RAND Conference Proceedings, 25 p. http://www.rand.org/pubs/conf_proceedings/CF124/CF124.chap1.html

46. Vishnevsky A.G. (Ed.) (2006). Demograficheskaja modernizacija Rossii, 1990-2000. Moskva: Novoe Izdatelstvo, 599 p.

47. Waite L.J., Lillard L.A. (1991). Children and Marital Disruption. The American Journal of Sociology, Vol. 96, No. 4. (Jan., 1991), pp. 930-953.

48. White L.K. (1990). Determinants of Divorce: A Review of Research in the Eighties. Journal of Marriage and the Family, Vol. 52, No.4, Family Research in the 1980s: The Decade in Review (Nov., 1990), pp. 904-912.

49. Zakharov S.V., Ivanova E.I. (1996). Fertility Decline and Recent Changes in Russia: On the Threshold of the Second Demographic Transition; in J. DaVanzo and G. Farnsworth (Eds.) Russia's Demographic “Crisis”. RAND Conference Proceedings, 32 p. http://www.rand.org/pubs/conf_proceedings/CF124/CF124.chap2.html

50. Zakharov S., Ivanova E. (2001). Vnebrachnie deti [Non-marital Children]. Naselenie i obtshestvo, No. 59, November. 
Appendix 1: Relative risks of divorce by motherhood status at marriage and parity and age of the youngest child; first time married women

\begin{tabular}{|c|c|c|c|}
\hline \multicolumn{4}{|l|}{ Duration of marriage } \\
\hline $1^{\text {st }}$ year & \multicolumn{3}{|l|}{1 (ref.) } \\
\hline $2^{\text {nd }}$ year & \multicolumn{3}{|l|}{$1.60^{* * *}$} \\
\hline $3^{\text {rd }}$ year & \multicolumn{3}{|l|}{$\begin{array}{l}1.60^{* * *} \\
1.77^{* * *}\end{array}$} \\
\hline $4^{\text {th }}$ year & \multicolumn{3}{|l|}{$1.80^{* * *}$} \\
\hline $5 t^{\mathrm{h}}$ year & \multicolumn{3}{|l|}{$1.66^{* * *}$} \\
\hline $6-7$ years & \multicolumn{3}{|l|}{$1.38^{* *}$} \\
\hline $8-9$ years & \multicolumn{3}{|l|}{1.28} \\
\hline $10+$ & \multicolumn{3}{|l|}{0.89} \\
\hline \multicolumn{4}{|l|}{ Period } \\
\hline$<1960$ & \multicolumn{3}{|l|}{$0.61 * *$} \\
\hline $1960-1964$ & \multicolumn{3}{|l|}{1 (ref.) } \\
\hline $1965-1969$ & \multicolumn{3}{|l|}{1.22} \\
\hline $1970-1974$ & \multicolumn{3}{|l|}{$1.75^{* * *}$} \\
\hline $1975-1979$ & \multicolumn{3}{|l|}{$1.89 * * *$} \\
\hline 1980-1984 & \multicolumn{3}{|l|}{$1.69 * * *$} \\
\hline 1985-1989 & \multicolumn{3}{|l|}{$1.52^{* *}$} \\
\hline 1990-1994 & \multicolumn{3}{|l|}{$1.79 * * *$} \\
\hline 1995-1999 & \multicolumn{3}{|l|}{$1.95^{* * *}$} \\
\hline $2000-2004$ & \multicolumn{3}{|l|}{$1.89^{* * *}$} \\
\hline $\begin{array}{l}\text { Motherhood status at marriage, } \\
\text { parity and age of youngest child }\end{array}$ & $\begin{array}{l}\text { Child(ren) } \\
\text { at marriage }\end{array}$ & $\begin{array}{l}\text { Pregnant } \\
\text { at marriage }^{1}\end{array}$ & $\begin{array}{l}\text { No child } \\
\text { at marriage }\end{array}$ \\
\hline Parity 0 & - & - & $3.55^{* * *}$ \\
\hline \multicolumn{4}{|l|}{ Parity 1 , aged $0-3$} \\
\hline aged 4-6 & $4.11^{* * *}$ & $4.09^{* * *}$ & $3.71^{* * *}$ \\
\hline aged 7+ & $3.36^{* * *}$ & $3.73^{* * *}$ & $2.34 * * *$ \\
\hline Parity 2+, aged 0-3 & $2.00 * *$ & 1.02 & 1 (ref.) \\
\hline aged 4-6 & 1.80 & $1.91^{*}$ & 0.98 \\
\hline aged 7+ & $2.02^{* * *}$ & 1.13 & 1.27 \\
\hline \multicolumn{4}{|l|}{ Age at 1st marriage } \\
\hline $15-18$ & \multicolumn{3}{|l|}{$1.98^{* * *}$} \\
\hline $19-22$ & $1.48^{* * *}$ & & \\
\hline $23-26$ & 1 (ref.) & & \\
\hline $27-29$ & 1.15 & & \\
\hline $30+$ & $0.65^{* * *}$ & & \\
\hline Parents ever divorced & & & \\
\hline Yes & 1.46 & & \\
\hline No & 1 (ref.) & & \\
\hline Place of residence & & & \\
\hline Moscow, St. Petersburg & $1.57^{* * *}$ & & \\
\hline Other oblast (regional) center & 1 (ref.) & & \\
\hline Other urban area & $0.84^{* *}$ & & \\
\hline Rural area & $0.70^{* * *}$ & & \\
\hline Religion group & & & \\
\hline Orthodox & 1 (ref.) & & \\
\hline Muslim & $0.45^{* * *}$ & & \\
\hline Other/missing & 0.98 & & \\
\hline Model fit & & & \\
\hline Initial LL & -4921 & & \\
\hline Final LL & -4494 & & \\
\hline
\end{tabular}


Appendix 2: Relative risks of divorce by motherhood status at marriage and calendar period; first-time married women

\begin{tabular}{|c|c|c|c|}
\hline \multicolumn{4}{|l|}{ Duration of marriage } \\
\hline $1^{\text {st }}$ year & 1 (ref.) & & \\
\hline $2^{\text {nd }}$ year & $1.65^{* * *}$ & & \\
\hline $3^{\text {rd }}$ year & $1.82^{* * *}$ & & \\
\hline $4^{\text {th }}$ year & $1.84^{* * *}$ & & \\
\hline $5 \mathrm{t}^{\mathrm{h}}$ year & $1.75^{* * *}$ & & \\
\hline 6-7 years & $1.48^{* *}$ & & \\
\hline 8-9 years & $1.36^{*}$ & & \\
\hline \multirow[t]{2}{*}{$10+$} & 0.91 & & \\
\hline & $\begin{array}{l}\text { Child(ren) } \\
\text { at marriage }\end{array}$ & $\begin{array}{l}\text { Pregnant } \\
\text { at marriage }\end{array}$ & $\begin{array}{l}\text { No child } \\
\text { at marriage }\end{array}$ \\
\hline$<1960$ & 0.47 & 1.04 & $0.58 * *$ \\
\hline 1960-1964 & 1.58 & 0.48 & 1 (ref.) \\
\hline 1965-1969 & 1.66 & 0.75 & 1.22 \\
\hline $1970-1974$ & $3.27^{* * *}$ & $2.75^{* * *}$ & $1.57 * *$ \\
\hline 1975-1979 & 1.70 & $3.70^{* * *}$ & $1.77^{* * *}$ \\
\hline 1980-1984 & $2.35^{* * *}$ & 1.61 & $1.65^{* * *}$ \\
\hline 1985-1989 & $2.62^{* * *}$ & $2.30 * * *$ & $1.36^{*}$ \\
\hline 1990-1994 & $2.05^{* *}$ & $1.80^{* *}$ & $1.79 * * *$ \\
\hline 1995-1999 & $3.23^{* * *}$ & $2.07 * * *$ & $1.85^{* * *}$ \\
\hline 2000-2004 & $3.29 * * *$ & $1.75^{* *}$ & $1.85^{* * *}$ \\
\hline \multicolumn{4}{|c|}{$\begin{array}{l}\text { Motherhood status at marriage, parity } \\
\text { and age of youngest child }\end{array}$} \\
\hline Parity 0 & $3.57 * * *$ & & \\
\hline Parity 1 , aged $0-3$ & $2.87^{* * *}$ & & \\
\hline aged $4-6$ & $3.54^{* * *}$ & & \\
\hline aged 7+ & $2.42^{* * *}$ & & \\
\hline Parity 2, aged 0-3 & 1 (ref.) & & \\
\hline aged $4-6$ & 0.98 & & \\
\hline aged 7+ & $1.42 *$ & & \\
\hline Parity 3+, aged 0-3 & 1.11 & & \\
\hline aged 4-6 & 1.53 & & \\
\hline aged 7+ & 0.65 & & \\
\hline \multicolumn{4}{|l|}{ Age at 1st marriage } \\
\hline $15-18$ & $2.02 * * *$ & & \\
\hline $19-22$ & $1.49 * * *$ & & \\
\hline $23-26$ & 1 (ref.) & & \\
\hline $27-29$ & 1.15 & & \\
\hline $30+$ & $0.65^{* * *}$ & & \\
\hline \multicolumn{4}{|l|}{ Parents ever divorced } \\
\hline Yes & $1.47^{* * *}$ & & \\
\hline No & 1 (ref.) & & \\
\hline \multicolumn{4}{|l|}{ Place of residence } \\
\hline Moscow, St. Petersburg & $1.57^{* * *}$ & & \\
\hline Other oblast (regional) center & 1 (ref.) & & \\
\hline Other urban area & $0.85 * *$ & & \\
\hline Rural area & $0.71^{* * *}$ & & \\
\hline \multicolumn{4}{|l|}{ Religion group } \\
\hline Orthodox & 1 (ref.) & & \\
\hline Muslim & $0.45 * * *$ & & \\
\hline Other/missing & 0.98 & & \\
\hline \multicolumn{4}{|l|}{ Model fit } \\
\hline Initial LL & -4921 & & \\
\hline Final LL & -4483 & & \\
\hline
\end{tabular}

*** $\mathrm{p}<0.01,{ }^{* *} \mathrm{p}<0.05, * \mathrm{p}<0.1$

Source: Russian GGS; author's calculations. 